\title{
Lysosomal storage disorders for the pediatric rheumatologist: the example of mucopolysaccharydoses
}

\author{
Rolando Cimaz, Angela Mauro \\ From 71st Congress of the Italian Society of Pediatrics. Joint National Meeting SIP, SIMGePeD, Study Group \\ on Pediatric Ultrasound, SUP Study Group on Hypertension \\ Rome, Italy. 4-6 June 2015
}

The Mucopolysaccharidoses (MPS) are a group of diseases caused by complete or partial deficiency of lysosomal enzymes responsible for glycosaminoglycans catabolism. Their accumulation within the lysosome leads to cellular damage and organ failure $[1,2]$.

The musculoskeletal system is the most frequently affected one. Joint stiffness, contractures (claw hand), dysostosis multiplex, and carpal tunnel syndrome are some of the most frequent features [3-9]. Often the joint symptoms may be confused with inflammatory arthritides such as Juvenile Idiopathic Arthritis [10,11]. A prompt differential diagnoses is a fundamental step: in MPS patients there are no signs of local inflammation such as swelling, warmth and tenderness, and lack of fever and increased inflammatory markers. In addition, patients with MPS do not respond to anti-rheumatic therapy $[12,13]$.

In addition, characteristic facies, cognitive impairment, short stature, recurrent otitis media, sleep apnea, hearing, vision and heart problems can be present $[14,15]$. Because of a wide variety of clinical presentation, diagnosis of MPS disorders is often delayed, especially in patients with mild forms and without neurocognitive impairment such as Scheie Syndrome.

When clinical features are suggestive for MPS, the diagnosis is confirmed with the assay of urinary GAG concentration, which is a sensitive but not specific method [16] and, as the gold standard with determination of the specific enzyme in cultured fibroblasts, leukocytes, plasma or serum [17]. The genetic sequencing could be used to identify the disease-causing mutation.

\footnotetext{
* Correspondence: r.cimaz@meyer.it

Department of Pediatrics, Rheumatology Unit, AOU Meyer Hospital; Viale Pieraccini, n²4; 50139, Firenze, Italy
}

(c) 2015 Cimaz and Mauro This is an Open Access article distributed under the terms of the Creative Commons Attribution License (http://creativecommons.org/licenses/by/4.0), which permits unrestricted use, distribution, and reproduction in any medium, provided the original work is properly cited. The Creative Commons Public Domain Dedication waiver (http://creativecommons.org/ publicdomain/zero/1.0/) applies to the data made available in this article, unless otherwise stated.
The managment of MPS disorders requires a multidisciplinary evaluation for multi-organ involvement. The new therapeutic approaches to MPS have drastically changed the natural history of disease. Transplantation of hematopoietic stem cells from bone marrow or umbilical cord can achieve significant benefits. The clinical success of this therapeutic approach depends on age, stage of disease, type of donor and ability to achieve stable engraftment without the development of graft-vshost disease $[18,20]$. In early stages of disease, enzyme replacement therapy can benefit musculoskeletal symptoms and lung function [21-23]. This therapy, however, does not cross the blood-brain barrier and has not shown neurocognitive benefit.

In conclusion, the goal is the prompt identification of MPS disorders since an early diagnosis could allow early treatment: in this regard, particular attention should be given to an accurate differential diagnosis with chronic inflammatory arthropathies.

Published: 30 September 2015

References

1. Muenzer J: Overview of the mucopolysaccharidoses. Rheumatology (Oxford) 2011, 50:4-12.

2. Neufeld EU, Muenzer J: The mucopolysaccharidoses. In The Metabolic and Molecular Bases of Inherited Disease. New York: McGraw-Hill;Scriver CR 2001:3421-52.

3. Aldenhoven M, Sakkers RJ, Boelens J, de Koning TJ, Wulffraat NM: Musculoskeletal manifestations of lysosomal storage disorders. Ann Rheum Dis 2009, 68:1659-65.

4. Schmidt $H$, Ullrich $\mathrm{K}$, von Lengerke $H J$, Kleine $M$, Brämswig J: Radiological findings in patients with mucopolysaccharidosis I H/S (Hurler-Scheie syndrome). Pediatr Radiol 1987, 17:409-14. mucopolysaccharidoses. Zhonghua Min Guo Xiao Er Ke Yi Xue Hui Za Zhi 1996, 37:178-84.
5. Chen SJ, Li YW, Wang TR, Hsu JC: Bony changes in common 
6. Montano AM, Tomatsu S, Gottesman GS, Smith M, Orii T: International Morquio A Registry: clinical manifestations and natural course of Morquio A disease. J Inherit Metab Dis 2007, 30:165-74.

7. Mikles M, Stanton RP: A review of Morquio syndrome. Am J Orthop 1997, 26:533-40.

8. Al-Qatan MM, Thomson HG, Clarke HM: Carpal tunnel syndrome in children and adolescents with no history of trauma. J Hand Surg 1996, 21B:108-11.

9. Yuen A, Dowling G, Johnstone B, Kornberg A, Coombs C: Carpal tunnel syndrome in children with mucopolysaccaridoses. J Child Neurol 2007, 22:260-3.

10. Morishita K, Petty RE: Musculoskeletal manifestations of mucopolysaccharidoses. Rheumatology (Oxford) 2011, 50:19-25.

11. Petty RE, Southwood TR, Manners P, Baum J, Glass DN, Goldenberg J, et al: International League of Associations for Rheumatology classification of juvenile idiopathic arthritis. second revision Edmonton, 2001. J Rheumatol 2004, 31:390-2.

12. Cimaz R, Coppa GV, Kone-Paut I, Link B, Pastores GM, Elorduy MR, et al: Joint contractures in the absence of inflammation may indicate mucopolysaccharidosis. Pediatr Rheumatol Online J 2009, 7:18.

13. Aldenhoven M, Sakkers RJ, Boelens J, de Koning TJ, Wulffraat NM: Musculoskeletal manifestations of lysosomal storage disorders. Ann Rheum Dis 2009, 68:1659-65.

14. Vijay S, Wraith JE: Clinical presentation and follow-up of patients with the attenuated phenotype of mucopolysaccharidosis type I. Acta Paediatr 2005, 94:872-7.

15. Thomas JA, Beck M, Clarke JT, Cox GF: Childhood onset of Scheie syndrome, the attenuated form of mucopolysaccharidosis. I. J Inherit Metab Dis 2010, 33:421-7.

16. Mahalingam K, Janani S, Priya S, Elango EM, Sundari RM: Diagnosis of mucopolysaccharidoses: how to avoid false positives and false negatives. Indian J Pediatr 2004, 71:29-32.

17. Hall CW, Liebaers I, Di Natale P, Neufeld EF: Enzymatic diagnosis of the genetic mucopolysaccharide storage disorders. Methods Enzymol 1978, 50:439-56.

18. Weisstein JS, Delgado E, Steinbach LS, Hart K, Packman S: Musculoskeletal manifestations of Hurler syndrome: long-term follow-up after bone marrow transplantation. J Pediatr Orthop 2004, 24:97-101.

19. Prasad VK, Kurtzberg J: Transplant outcomes in mucopolysaccharidoses. Semin Hematol 2010, 47:59-69.

20. Boelens JJ, Wynn RF, O'Meara A, Veys P, Bertrand Y, Souillet G, et al: Outcomes of hematopoietic stem cell transplantation for Hurler's syndrome in Europe: a risk factor analysis for graft failure. Bone Marrow Transplant 2007, 40:225-33.

21. McGill JJ, Inwood AC, Coman DJ, Lipke ML, de Lore D, Swiedler SJ, et a: Enzyme replacement therapy for mucopolysaccharidosis VI from 8 weeks of age-a sibling control study. Clin Genet 2010, 77:492-8.

22. Schulze-Frenking G, Jones SA, Roberts J, Beck M, Wraith JE: Effects of enzyme replacement therapy on growth in patients with mucopolysaccharidosis type II. J Inherit Metab Dis 2011, 34:203-8.

23. Wraith JE, Beck M, Lane R, van der Ploeg A, Shapiro E, Xue Y, et al: Enzyme replacement therapy in patients who have mucopolysaccharidosis I and are younger than 5 years: results of a multinational study of recombinant human alpha-L-iduronidase (laronidase). Pediatrics 2007, 120:e37-46.

doi:10.1186/1824-7288-41-S2-A17

Cite this article as: Cimaz and Mauro: Lysosomal storage disorders for the pediatric rheumatologist: the example of mucopolysaccharydoses. Italian Journal of Pediatrics 2015 41(Suppl 2):A17.

\section{Submit your next manuscript to BioMed Central and take full advantage of:}

- Convenient online submission

- Thorough peer review

- No space constraints or color figure charges

- Immediate publication on acceptance

- Inclusion in PubMed, CAS, Scopus and Google Scholar

- Research which is freely available for redistribution

Submit your manuscript at www.biomedcentral.com/submit
C Biomed Central 